\title{
Profitability of Non Timber Forest Products Collected in Arakanga Forest Reserve, Abeokuta Ogun State, Nigeria
}

\section{${ }^{*}$ BAABATUNDE, TO; ${ }^{2}$ BABATUNDE, OO; ${ }^{3}$ BABATUNDE, KO; ${ }^{4}$ OLUWALANA, T; ${ }^{5}$ ADULOJU, AR}

\author{
${ }^{*}$ Department of Forestry Technology, Federal College of Forestry, Ibadan Oyo State, Nigeria \\ ${ }^{2}$ Department of Wood and Paper Technology, Federal College of Forestry Ibadan, Oyo State, Nigeria \\ ${ }^{3}$ Department of Basic Sciences, Federal College of Wildlife Management, New Bussa, Niger State, Nigeria \\ ${ }^{4}$ Department of Basics and General Studies, Federal College of Forestry Ibadan, Oyo State, Nigeria \\ ${ }^{5}$ Department of Agricultural Technology, Federal College of Forestry, Ibadan, Oyo, Nigeria \\ *Corresponding Author Email: Sollybee2012@gmail.com; Tel: 08033948859
}

\begin{abstract}
The study investigated evaluation of economic impact of non-timber forest products collections in Arakanga forest reserve in Ogun State. Purposive sampling was used to select four villages around the reserve, representing $10 \%$ sampling intensity in the study area. A total of 98 questionnaires were administered. Data were analyzed using descriptive statistics and budgetary analysis. Majority of respondents were within the age group of 40-49 years $(35.7 \%)$ and mostly were female $(51 \%), 40.8 \%$ had no formal education while $33.7 \%$ had primary education and were mostly married(57.1\%). Identified NTFPs includes fuelwood, mushroom, charcoal and honey. The result on profitability showed that fuel-wood had the highest net profit $(\mathrm{N} 10,916.85)$ among the NTFPs found in the study area. Constraints faced NTFPs were price fluctuation (58.2\%), low demand (14.3\%) and inadequate credit facilities (11.2\%) and host of others. It was recommended that NTFPs should be introduced to youth in order to reduce the level of unemployment and government should repaired the road network to the forest for easy accessibility for NTFPs operation.
\end{abstract}

\section{DOI:https://dx.doi.org/10.4314/jasem.v24i4.3}

Copyright: Copyright (C) 2020 Babatunde et al. This is an open access article distributed under the Creative Commons Attribution License (CCL), which permits unrestricted use, distribution, and reproduction in any medium, provided the original work is properly cited.

Dates: Received: 10 February 2020; Revised: 20 March 2020; Accepted: 28 March 2020

Keywords: profitability, Arakanga, constraint, collections, forest reserve

Forests have been central to human survival for as long as we have inhabited the earth. How people use and value forests at a particular place and time, however, depends in large part on their scarcity or abundance relative to changing human needs. In recent years, human population growth, migration and industrialization, with other socio-economic changes have had a dramatic impact on the world's forestry sources. Deforestation in tropical regions is widely acknowledged as a global problem, as is the decline in so-called "old-growth" forests in all countries (Barbieret al., 2009). The recent increase in secondary forests in temperate regions, while less well-known, will also have a profound effect on the future supply of forest goods and services (Arnold 2001; Sedjo\& Lyon 2000). Meanwhile, human demands on forests are changing rapidly, as we become more aware of the important environmental benefits they provide. Millions of people across the developing world trade in a diverse range of non-timber forest produce (NTFPs) everyday, which are marketed primarily in local and regional domestics markets (Schanker et al.,
2004). Building materials, fuel wood, charcoal, indigenous foodstuffs, medicines, crafts items (from wood, grass, reeds, and vines), such as resins, honey, oils and alcoholic beverages are examples of some of products that may be found for sale in the vast majority of rural markets and in nearby towns and cities (Shackleton et al., 2007). NTFPs were for long overshadowed by timber products and has received increased policy and research attention only in the last few decades. This policy and research attention was based on three propositions (Arnold and Ruiz-Perez 2001): The first was that NTFPs contribute significantly to the livelihood and welfare of households living in and adjacent to forest. Secondly, exploitation of NTFPs is ecologically less destructive than timber harvesting and other forest products: Lastly, NTFPs production and development provides a foundation for sustainable economic development and could reduce tropical deforestation. These proposition encouraged researchers to put effort in the determination of monetary values of NTFPs as well as their contribution to overall livelihoods. For instance, 
studies by Makawia (2014) show that NTFPs contribute $50 \%$ to the total livelihood income in some areas and less than $20 \%$ in others. Understanding the changing pattern of land use and environmental preferences is essential to a better understanding of the current debate on forest policy, which is raging at global, national and local levels. Calls for increased forest conservation, timber certification and trade policy reforms, more "sustainable" forest management and other initiatives are driven by growing concern that the world's forests will require more protection and better management if they are to meet future human needs, including demand for both timber and non-timber forest goods and services. (FAO, 2002) this marked the start of the present emphasis on rural people's livelihoods. In the 2000s till date on, nontimber forest products (NTFPs) emerged as potentially important in simultaneously meeting rural development and forest conservation objectives (Panayotouet al., 2004). Alongside the increasing acceptance of people-oriented forestry and sustainable development concepts (Brown 2003), it was argued that NTFPs could contribute positively and significantly to improving rural livelihoods and natural resource management. However, this argument was and is based on a number of, often implicit, assumptions which, in combination with differences in objectives and methods across studies, makes it very difficult to generalize findings at present, though it is being attempted (Tewari, 2000).

Economic valuation of forests is an important tool for making more informed decisions about the use of forest lands. A number of reliable methods have been developed to assign monetary values to non-marketed or non-timber forest benefits. There are important differences in the significance of different non-timber forest benefits in developed and developing countries, with implications for the choice of valuation methods (Barbier, et al., 2000). Economists use the term "total economic value" to refer to the various benefits which may be obtained from a natural resource. These benefits include the direct use value of a resource as an input to production or as a consumption good, its indirect use value through protecting or sustaining economic activity, and its non-use value to people who derive satisfaction the mere existence of a resource, even though they may never see it or consume any product obtained from it (Pearce et al., 2008). Examples of direct use values in forestry include timber and non-timber products, but also non commodity benefits such as forest recreation. Indirect use values include the role of forests in protecting watersheds and fisheries, and the storage of carbon in trees (to offset the atmospheric accumulation of "greenhouse" gases implicated in global warming).
Non-use values in forestry comprise such intangible benefits as the continued existence of certain species of wildlife, which the general public wishes to protect for posterity (Arnordet al., 2001). The scope of study is to, identify and determine the profitability of NTFPs collected in Arakanga Forest Reserve.

\section{MATERIALS AND METHODS}

Area of Study: This study was carried out in Arakanga Forest Reserve (AFR). It is one of the 9 forest reserves in Ogun State with a land area of about $2.39 \mathrm{~km}$. The reserve is predominantly of high forest and savanna vegetation type. It is situated at the border between Abeokuta North and Opeji ward of Odeda Local Government Area. Arakanga Forest Reserve is a peri urban forest (Konijnendijk et al., 2004). A peri -urban forest reserve has been described as trees and forest resources outside but close to urban areas because they are major contributors of goods and services to urban society (Mbwambo et al., 2014). Arakanga Forest Preserve (Arakanga Forest Preserve) is a forest reserve (class L - Area) in Ogun State (Nigeria (general)), Nigeria (Africa) with the region font code of Africa/Middle East. It is located at an elevation of 71 meters above sea level and its population amounts to 118,097 .Its coordinates are $7^{\circ} 10^{\prime} 60^{\prime \prime} \mathrm{N}$ and $3^{\circ} 21^{\prime} 0^{\prime \prime} \mathrm{E}$ in DMS (Degrees Minutes Seconds) or 7.18333 and 3.35 (in decimal degrees). Its UTM position is EH39. and its Joint Operation Graphics reference is NB3103.Current local time is 19:46; the sun rises at 08:06 and sets at 20:13 local time (Africa/Lagos UTC/GMT+1). The standard time zone for Arakanga Forest Preserve is UTC/GMT+1.

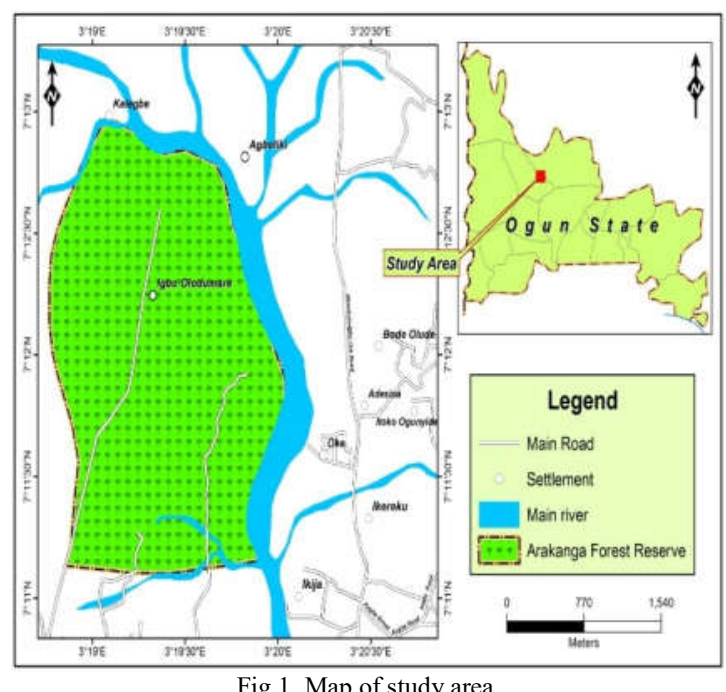

A Forest reserve is a forested area set aside for preservation or controlled use. This study was carried 
out at Arakanga Forest Reserve, Abeokuta, Ogun State to determine the contribution of the reserve to livelihoods of the people in the neighbourhood. Four (4) communities was selected, they are, Ajegunle, Ibode-Olude, quarry, and Mawuko to determine the productivity line among the respondents. The total number of 100 Questionnaire was used to collect information from the respondent however only 98 Questionnaire was used for this study.

Sampling Technique and Data Collected: Purposive sampling was used to select four villages (Ajegunle, Ibode-Olude, Mawuko, Quarri) which are close to the forest reserve with projected population of 200 , 220,260 and 600 respectively. Furthermore, Diawet al., (2002) was used to select respondents for the study which indicate $10 \%$ sampling intensity was used to sample respondents in the study area where the population is less than $500,5 \%$ sampling intensity for population between 500 and 1000 and $2.5 \%$ for the population above 1000 .

In light of this, 20 questionnaires in Ajegunle, 22 in ibode-olude, 26 in Mawuko and 30 in Quarri, making a total of 98 questionnaires were distributed in the study area.

In addition, questionnaires were administered to the respondents in which the questionnaire was read and interpreted to the illiterate respondents.

Data Analysis: Descriptive statistics tools such as frequencies, means, modes and percentages were used to analyze the variables of interest such as age, gender, family size, education, income, religion, how they transport products from collection point to sales point and the amount paid to laborers. Budgetary analysis was also employed to determine the profitability of the NTFPs collected.

The data collected were subjected to frequency, percentage and profitability analysis.

Gross Margin $=$ Total revenue - Total marketing cost Profitability index=Rate of return on investment

$$
\frac{\mathrm{TR}-\mathrm{TC}}{\mathrm{TC}} \times 100
$$

Where $\mathrm{GM}=\mathrm{TR}-\mathrm{TC} ; \mathrm{TR}=$ Output $(\mathrm{kg}) *$ price/Unit; $\mathrm{TC}=\mathrm{X}_{1} \mathrm{P}_{1}+\mathrm{X}_{2} \mathrm{P}_{2}+\mathrm{X}_{3} \mathrm{P}_{3}+-\quad-\quad-\mathrm{X}_{\mathrm{n}} \mathrm{P}_{\mathrm{n}} ;$ and $\mathrm{X}_{1}=$ transportation; $\mathrm{X}_{2}=$ labour (\#); $\mathrm{X}_{3}=$ Cutlass; $\mathrm{X}_{4}=$ knife; $\mathrm{X}_{5}=$ Basket; $\mathrm{X}_{6}=$ bottle; $\mathrm{P}-=$ price of input

\section{RESULTS AND DISCUSSION}

Table 1 shows the demographic characteristics of the respondent, information on gender shows that $51 \%$ of the respondents are females while $(49 \%)$ were male that are involved in the collectors of NTFPs in the study area. This is in constraints to the findings of SaniYahaya (2005) who stated that men's contribution to economic life and share in the labour force continues to rise as they are becoming more involved in small scale enterprises such as agricultural processing and marketing.

\begin{tabular}{|c|c|c|}
\hline Demographic & $\begin{array}{l}\text { Frequency } \\
\mathrm{N}=98\end{array}$ & $\begin{array}{l}\text { Percentage } \\
100 \%\end{array}$ \\
\hline \multicolumn{3}{|l|}{ Villages } \\
\hline Ajegunle & 20 & 20.4 \\
\hline Ibode- olude & 22 & 22.4 \\
\hline Mawuko & 26 & 26.5 \\
\hline Quarri & 30 & 30.7 \\
\hline \multicolumn{3}{|l|}{ Gender } \\
\hline Male & 48 & 49.0 \\
\hline Female & 50 & 51.0 \\
\hline \multicolumn{3}{|l|}{ Age } \\
\hline $20-29$ & 13 & 13.3 \\
\hline $30-39$ & 26 & 26.5 \\
\hline $40-49$ & 35 & 35.7 \\
\hline $50-59$ & 21 & 21.4 \\
\hline Above 60 & 3 & 3.1 \\
\hline \multicolumn{3}{|l|}{ Educational Level } \\
\hline No Formal Education & 40 & 40.8 \\
\hline Primary Education & 33 & 33.7 \\
\hline Secondary Education & 20 & 20.4 \\
\hline \multicolumn{2}{|l|}{ Marital status } & 5.1 \\
\hline Single & 5 & 5.1 \\
\hline Married & 56 & 57.1 \\
\hline Divorced & 22 & 22.4 \\
\hline Window/Widower & 15 & 15.3 \\
\hline \multicolumn{3}{|l|}{ Household size } \\
\hline $1-3$ & 10 & 10.20 \\
\hline $4-6$ & 49 & 50.0 \\
\hline $7-9$ & 29 & 29.6 \\
\hline 10 above & 10 & 10.2 \\
\hline \multicolumn{3}{|l|}{ Religion } \\
\hline Christianity & 51 & 52.0 \\
\hline Islam & 37 & 37.8 \\
\hline Traditional & 10 & 10.2 \\
\hline
\end{tabular}

The respondents within the age distribution shows that $35.7 \%$ of the respondents were between the age ranges of $40-49$ years, $26.5 \%$ were in the range of $30-$ 39 years, $21.4 \%$ on the range of $50-59$ years followed by $13.3 \%$ were in the range of $20-29$ years while age within range of $3.1 \%$ accounted for above 60years. This implies that majority of the respondents were young and still possess enough strength vigour and vitality to play their active roles in agriculture related entrepreneur. This is agreed with Salawu (2011) who stated that the highly productive age in agricultural and all forestry activities fall with the age group of 40-49 years. The result revealed that $40.8 \%$ of the total respondents were with no formal education, $33.7 \%$ were with primary education, while respondents with secondary education had $20.4 \%$ and respondents with 
tertiary had $5.1 \%$. While a very few percentage of the respondent possess tertiary education. It therefore supported the findings of Awe et al., (2011) that although education is an engine for development, it is not necessarily needed for the forest dependent communities as their utmost concern is the easy, cheap and readily available farm practice and non-timber forest products gathering in other to sustain livelihood. It was further revealed that $(57.1 \%)$ of the respondents were married, $5.1 \%$ were single, also $22.4 \%$ were divorced, while $15.3 \%$ were widow/widower. This implies that majority of the respondents were married and committed to the collection of non-timber forest products in the study area in order to take care of the family needs. This however supported the findings of Jibowo (2000) who stated that high percentage of the rural population were married. And also supported with the findings of Afolayan (2000) who stated that majority of people engaged in collection of Non-
Timber Forest Products are married. The table further shows that the respondents practiced Christianity and Islam, but majority $(52.0 \%)$ were Christian while $37.8 \%$ practice Islam and $10.2 \%$ are traditionalist. The result on household showed that respondents with 4-6 recorded the highest percentage with $50 \%$. This was followed by those with household between 7-9 persons with $29.6 \%$ while those with $1-3$ and 10 above accounted for $10.2 \%$. This signifies that the household head employs family activities, however, the household size is function is a function of the income of the family as this will lead to a pull of resources together for a better standard of living. This is in line with the findings of Awe et $a$. (2011) who stated that non-timber forest products collection and gathering is a collective effort which requires more hands hence the use of family labour is required.

Table 2Cost (in Naira) and Returns to Non-Timber Forest Products

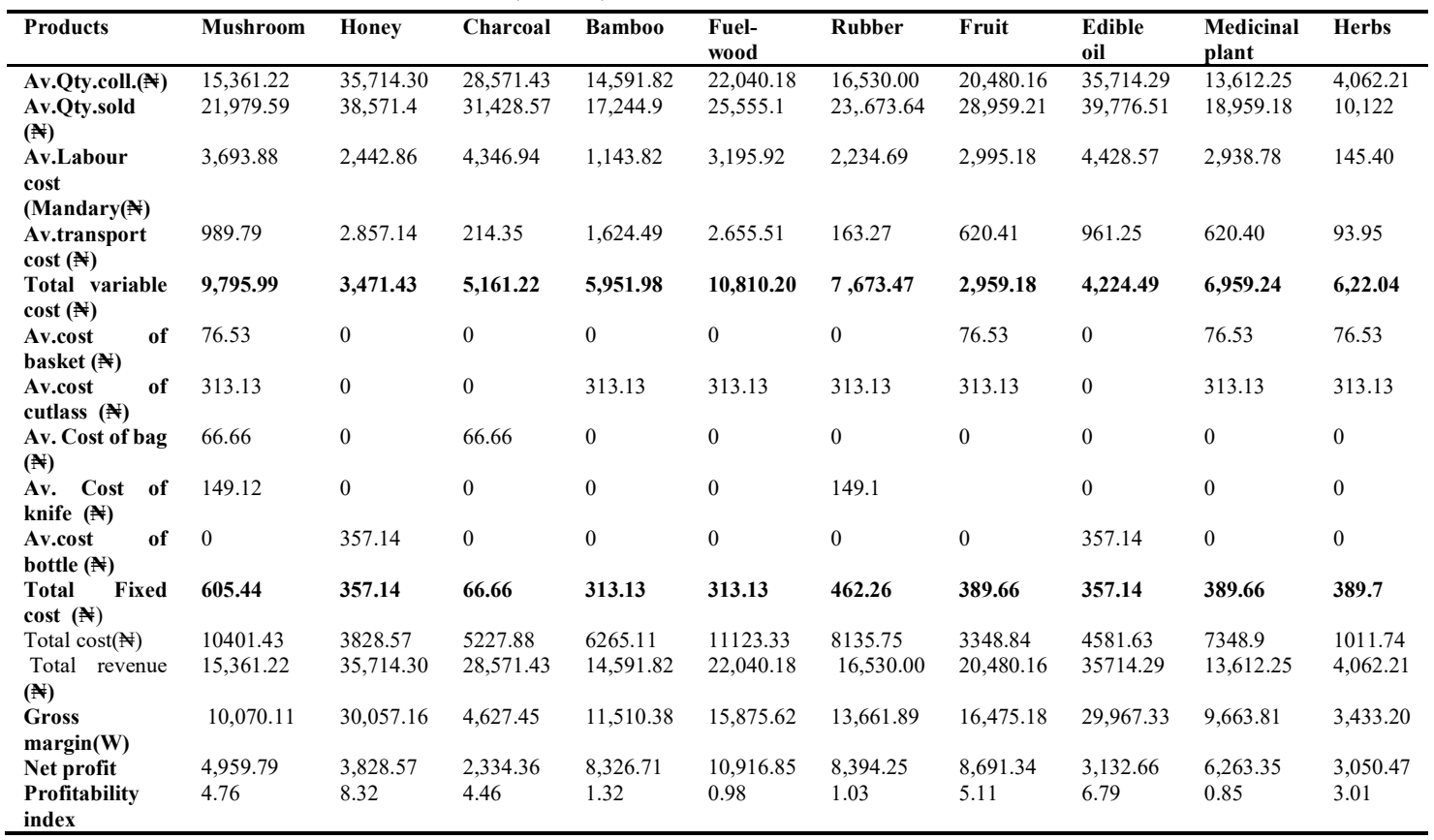

Source: field survey 2019.

The table above shows the budgetary analysis of the NTFPS collected in Arakanga Forest Reserve. The total variable cost for the products are ,(mushroom) $\$ 9,795.99$, (honey) $\$ 3,471.43$, (charcoal) $\$ 5,161.22$, (bamboo) \$5,951.98, (fuel-wood) $\$ 10,810.20$, (rubber) \#7,673.47, (fruits) $¥ 2,959.18$, (edible oil) $¥ 4,224.49$, (medicinal plant) $¥ 6,959.24$, (herbs)

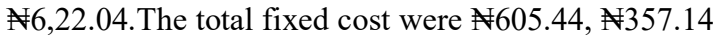
, 66.66, $313.13 ， \AA 313.13 ， \$ 462.26 ， \$ 389.66$, $¥ 357.14, \cdots 389.66, \$ 389.7$. The total revenue realized were $\$ 15,361.22 \quad \$ 35,714.30, \quad \$ 28,571.43$, N14,591.82, $22,040.18, N 16,530.00, N 20,480.16$, $¥ 35,714.29, \cdots 13,612.25, \$ 4,062.21$. The net profit are $¥ 4,959.79, \approx 3,828.57, \quad 2,334.36$, 8,326.71, N10,916.85, 8,394.25, 8,691.34, $33,132.66$, $¥ 6,226.35,03,050.47$. Its shows that fuel-wood had the highest net profit ( $10,916.85)$ among the NTFPs in the study area. The rate of return is as follows mushroom (4.76\%), honey $(8.32 \%)$, charcoal $(4.46 \%)$, bamboo( $1.32 \%)$, fuel-wood $(0.98 \%)$, rubber(1.03\%), 
fruits(5.11\%), edible oil(6.79\%), medicinal plant $(0.85 \%)$, herbs(3.01\%). This results indicates that for every naira invested (also known as return to capital) was high in the study area.1- $\$ 8$ was realized and the rates of return follow the same trend. On the basis of this the collection of NTFPs were more profitable in Arakanga forest reserve.

Table 3: Constraint of Non Timber Forest Products inArakanga

\begin{tabular}{lll}
\multicolumn{3}{c}{ Reserve } \\
\hline Constraints & Frequency & Percentage \% \\
\hline Low demand & 14 & 14.3 \\
Price fluctuation & 57 & 58.2 \\
Inadequate credit facilities & 11 & 11.2 \\
High transportation & 6 & 6.1 \\
Storage problem & 10 & 10.2 \\
TOTAL & 98 & 100 \\
\hline
\end{tabular}

Source: Field Survey, 2019.

The table shows that the collection of NTFPs in the study area encounters several constraints. Majority $14.3 \%$ of the respondent are face with low demand which implies that customer demand for NTFPs are very low which is in line with UNEP-WCMC,(2006) study. $58.2 \%$ are face with price fluctuation which is in line with Wilkinson, (2004) which state that market expanded at a rate of $13 \%-15 \%$ annually. $11.2 \%$ were facing with inadequate facilities which implies that majority of the rural dwellers as no access to credit facilities which is in line with chamber lain (1998). NTFPs contribute significantly to local and regional economics. $6.1 \%$ usually facing the challenges of high transportation which implies that bad road usually affect the rate at which the villagers participated in the collection of NTFPs in the study area. Lastly $10.2 \%$ were the respondents that is facing with the storage facilities most of theNTFPs collected usually spoil and make farmers effort wasted and make customer interest reduce in the consumption of the products

Conclusion: The study shows that Non-Timber Forest Products have the potential ability to sustain lives in the rural area. The importance of Non- Timber Forest Products cannot be over-looked in the ability to sustain livelihood. It's required no certificate (education) before one can take part in the collection and sales of NTFPs. It requires little capital and the turnover is great. Based on the collection of non-timber forest products by a large majority of the people living in the study area and coupled with the role they play in meeting the basic needs and sustaining livelihood, it can be concluded that there are wide range of nontimber forest products in Arakanga Forest Reserve such as mushroom, honey, charcoal, bamboo, fuel wood, rubber, medicinal plant, fruits, herbs, edible oil. It is conclude that the collection of NTFPs is viable and will be a sustainable potential for income generation. The rural dwellers of the study area should encouraged to cultivate the cultivable non-timber forest products for continuous income generation. The youth should be informed about the importance and benefits of Non-Timber Forest Products. Community forestry should also be encouraged the state government and Non-Governmental Organizations by educating them through seminal, constructing the road for adequate transport of NTFPs and assisting the foresters in protecting the forest from encroachers and illegal felling constructing the road for adequate transport of NTFPs.

\section{REFERENCES}

Adepoju, AA and Salau, S (2007): Economic valuation of Non-Timber Forest Products (NTFPs); April 9, 2007. Munich Personal RePEc Journal Archivehttp://mpra.ub.unimuenchen.de/2689/mp ra, paper No. 2689, Pp $1-17$. Posted $7^{\text {th }}$ November 2007/ 02:40.

Aderounmu, AF, Ladipo, DO, Adebisi, AA, Adewusi, HG and Oyeleke, GO (2002): Nigeria chew stick species; diminishing non-timber forest resources with immense commercial potentials: Forestry and Challenges of Sustainable Livelihood; proceedings of the $28^{\text {th }}$ Annual Conference of the Forestry Association of Nigeria. $4^{\text {th }}-8^{\text {th }}$ Nov. 2002. Pp $119-126$.

Ariyo, BD (2010): Poverty Situation in Nigeria, An overview of rural development institutions. Pakistan Journals of Social sciences. 7 (5) 351 356.

Arnold, JEM (1995): Poverty and Conservation Society and Non-Timber Forest Products in Tropical Asia. Ed. Fox J. Occasional paper No. 19, East West Centre; Honolulu, Hawaii USA.

Arnold, M.2001. Forestry Expansion: A Study of Technical, Economic and Ecological

Factors. Oxford Forestry Institute Paper No 3. Oxford.

Barbier, EB. (2000). The Economic Value of Ecosystems: 2 - Tropical Forests. London Environmental Economics Centre Gatekeeper Series No 91-01. International Institute for Environment and Development. London.

Barbier, EB, Burgess, JC, Bishop, J and Aylward, B (2009): The Economics of the Tropical Timber Trade. Earthscan. London. 
Baumol, W; Oates, WE (2013): The Theory of Environmental Policy (Second Edition).Cambridge University Press. Cambridge.

Emery, M (1998): Seeing, Gathering, Managing Special Forest Products and Public Land Management in Proc, Special Forest Products; working together in a changing world. Western Forestry and Conservation Association. Portland Oregon. Pg 31

FAO (1983): Food and Agricultural Organization of the United Nation; Simple Technologies for Making Charcoal. Rome, 1983. Pgs 1, 8, 9, 99

FAO. (2007): State of the World's Forests. Food and Agriculture Organization of the United Nations. Rome.

FAO (2001) Handbook on assessment of Non-Timber Forest Products in Forest community Forestry. No.3 pp.75-99 Gammage, S (1997): Estimating the Returns to Mangrove Conversion: Sustainable Management or Short Term Gain? Environmental Economics Discussion Paper No 97-02. International Institute for Environment and Development. London.

Garrod, G and Willis, K (2005): "The environmental economic impact of woodland: a two-stage hedonic price model of the amenity value of forestry in Britain". Applied Economics 24:715728.

Gbadebo, JO and Gloria U (2009): The Non-wood Forest Products of Nigeria. A report produced as output of the EC-FAO partnership program (1998 -2000) project gcp/int/679/ec.

Gibb, H (2007). Gender dimensions of intellectual property and traditional medicinal knowledge. Background study for the Gender and Trade Policy Paper prepared for UNDP. Asia-Pacific

Trade and Investment Initiative, UNDP Asia-Pacific Regional Centre, Colombo, Sri Lanka.

Gordon C. 2004. News: The new taste of chocolate in Europe,www.newworldchocolatesociety.com/ind ex/php/nwcs/comments/news-eurochoctaste.

Hammett A and Chamberlin, JL (1998): Sustainable use of Non-traditional Forest Product. Alternative Forest Based Income Opportunities in Natural Resources Income Opportunities on Private Land
Conference. April 5 - 7, 1998. Hagerstown, Maryland Ed. Jonathan, SKpg 141 - 147.

Hanley N and Milne, J (1996): "Ethical Beliefs and Behavior in Contingent Valuation Surveys". Journal of Environmental Planning and Management 39 (2): 255-272.

Kramer RA, Sharma, N and Munasinghe, M (2005): Valuing tropical forests: methodology and case study of Madagascar. Environment Paper No 13. The World Bank. Washington DC.

Makawi AM (2003): The Measurement of Environmental and Resource Values. Resources for the Future. Washington DC.

Maler KG (2002): "Production Function Approach in Developing Countries". In: Vincent, JR, Crawford, EW and Hoehn, JP (eds.) Valuing Environmental Benefits in Developing Countries. Special Report 29. Michigan State University.

McGrath, P 2003. Water hyacinth spawns mushroom enterprise. New Agriculturalist online, 1 May.

Meregini AO (2002): Strategies for increased firewood production in South Eastern Nigeria. Forestry and Challenges of Sustainable Livelihood; Proceedings of the $28^{\text {th }}$ Annual Conference of the Forestry Association of Nigeria. 4 - 8 Nov.2002. pg 366 - 375 .

MirjamAF, Rose-Tonen T and Freerk KW (@003): The importance of Non-timber forest products for forest based rural livelihood; an evolving research agenda. Paper presented at the International Conference on Rural Livelihood, Forest and Biodiversity. Pp 19 - 23. May, 2003. Bonn, Germany.

Munasinghe M and Lutz, E (2014): "Environmental economics and valuation indevelopment decision making”. In Munasinghe, M (ed.) 2003. Environmental economics and natural resource management in developing countries. Committee of International Development Institutions on the Environment. The World Bank. Washington DC.

OECD. (2009). Economic Instruments for Environmental Protection. OECD. Paris.

Okafor (2004).Omoradion FI and Amaja B (1994): Non-timber Forest Products (Nigeria): 
Consultancy paper prepared by the Tropical Forest Action Programme. Pp 6-8.

Pearce DW, Markandya A and Barbier EB (2008): Blueprint for a Green Economy. Earths can London.

Perez-Garcia JM and Lippke BR (2001): The Timber Trade and Tropical Forests: Modeling the Impacts of Supply Constraints, Trade Constraints and Trade Liberalization. London Environmental Economics Centre Discussion Paper No 93-03. International Institute for Environment and Development. London.

Portney PR (2000): Public Policies for Environmental Protection. Resources for the Future, Washington DC.

Saniyahaya kesanAmalanpengurusanpengupayaandalampeng ajaranpembelajaran.pp.1, 5, 9

Schanker SS, Cropper M.L. and Oates W.E. (2004): "Environmental Economics: A Survey". Journal of Economic Literature 30: 675-740.

Sedjo RA and Lyon KS (2000): The Long-Term Adequacy of World Timber Supply. Resources for the Future. Washington DC.

Shackleton AS, Brown K and Pearce DW (2007): The Causes of Tropical Deforestation. University College London Press. London.

Sharma NP (2002): Managing the World's Forests: Looking for Balance between Conservation and Development. Kendall/Hunt Publishing Company.
Sastry CB (2005). Rattan in the 21 st century - an overview. Unasylva (FAO) No. 205.

Teawri F, Arrow K., Solow R., Portney PR, Leamer EE, Radner R. and Schuman H. (2000): "Report of the National Oceanic and Atmospheric Administration Panel on Contingent Valuation". Federal Register 58: 4601-4614.

UNEP-WCMC 2006. Commercialization of nottimber forest products factors influencing success. Lessons learned from Mexico and Bolivia.http://www.odi.org.uk/publications/2882commercialisation-non-timber-forest-productsfactors-influencing-success Wilkinson, K \& C. Elevitch 2004. Non-Tiber-Forest Products: an introduction. The Overstory \#53. www.agroforestry.net

Willis KG, Garrod GD; Chee Tong Yiew (1998): "Valuation and Analysis of Consumer Demand for Forest Recreation Areas in Peninsular Malaysia" in Lee SuSeeet al (eds) Conservation, Management and Development of Forest Resources.Proceedings of the Malaysia-United Kingdom Programme Workshop. Forest Research Institute Malaysia.

Yakubu FB; Iduma FO (2002): Processing and Marketing of Charcoal in selected Local Government Areas of Oyo State, Nigeria. Forestry and Challenges of Sustainable Livelihood; Processing of the $28^{\text {th }}$ Annual Conference of the Forestry Association of Nigeria. 4 - 8 Nov. 2002. Pg $167-177$. 